\title{
Household Requirements Versus Profit Optimization: The Win-Win Solution Strategies Among Small-Holder Farmers in South Western Nigeria
}

\author{
O. R. Adeniyi ${ }^{1} \&$ C. A. Adesina ${ }^{1}$ \\ ${ }^{1}$ Department of Agricultural Economics and Extension, Bowen University, Iwo, Osun State, Nigeria \\ Corresponding author: O. R. Adeniyi, Department of Agricultural Economics and Extension, Bowen University, \\ P.M.B. 284, Iwo, Osun State, Nigeria. Tel: 234-803-581-0932. E-mail: adeniyiwamiwa2008@yahoo.com
}

Received: October 22, 2013 Accepted: November 7, 2013 Online Published: December 15, 2013

doi:10.5539/jas.v6n1p66 URL: http://dx.doi.org/10.5539/jas.v6n1p66

\begin{abstract}
Satisfaction of household requirements and profit maximization has been the main goals of subsistence small-holder farmers in the rural communities of Nigeria. This necessitated the practice of multiple/mixed cropping of arable crops. On the contrary, a part of the National food security agenda of the Federal government is the raising of maize sole to meet the need of local consumers as well as export market. The need to chat a middle course for meeting the requirements of all the parties concerned calls for this study. Data used were obtained from well organized and supervised rural farmers in south-western Nigeria and analyzed by using budgeting and linear programming. Results obtained from the use of Linear programming techniques have demonstrated that mixed cropping involving maize/cocoyam, maize/cassava/yam and cassava/yam are more rewarding in terms of profits and satisfaction of subsistence goals on small-holder farms in south western Nigeria. This contrasts diametrically with sole cropping of maize which has been the priority of the agricultural extension departments of the ministries of agriculture in tune with government programme. The use of parametric programming suggests that increase in farm size, introduction of labour-enhancing technologies and improved production techniques would raise returns from sole cropping of maize to a competitive level and thus resolve the empirical conflict.
\end{abstract}

Keywords: household requirements, subsistence goals, parametric programming, competitive level, empirical conflict

\section{Introduction}

Small-holder farmers constitute about 95 percent of Nigerian farming population (Attah, 2012; Oluwasola, Kasali \& Amusan, 2012; Olayide, 1976). Therefore as a policy strategy towards developing the agricultural sector, government should make the small farmers the centre-piece (Enriquez, 2000; Idachaba, 2004; Oni, 2008). However, the small-holder farmer's twin goal of satisfying the family food subsistence need (Adeniyi,2012) and making remunerative income (profits) from his farming activity (Olayide, 1976) contrasts with the current government agricultural development strategy of having profit maximization as the only goal(Zhou, 2013). Thus, government agricultural extension services recommend (Adesimi \& Ladipo, 1983) and encourage sole cropping at least of improved varieties of maize among small-holder farmers whereas majority of farmers continue to practice mixed cropping (Giller, Witter, Corbeds, \& Tittonell, 2009). In a bid to reconcile the observed conflict and give effect to government agricultural development strategy, this study centred on using the conventional linear programming (LP) techniques and sensitivity analysis to find the optimal enterprise combination when:

(i) profit maximization is the only assumed goal of the farmer,

(ii) subsistence goal is combined with profit maximization goal of the farmer; and on the basis of (i) and (ii) above;

(iii) to find out if there is any discrepancy and

(iv) to resolve such conflict, if any.

\section{Data Sources}

This study was conducted in 10 of the member group of villages that make up Isoya Rural development Project (IRDP), an outreach project of the Faculty of Agriculture, ObafemiAwolowo University, Ile-Ife, covering 13 small 
villages privileged with a lot of extension input since the last 40 years. The project planned for serving as a laboratory for Social and Economic research started in 1970 under the aegis of the Department of Agricultural Extension and Rural Sociology of the Faculty.

Isoya village, the administrative headquarters of the group of villages, is 14 kilometres to the University on the eastern part of Ife-Ondo road and the farthest of the villages (Ladin) is about 17 kilometres. The operational area of IRDP lies approximately between latitude $7^{\circ} 28^{\prime}$ North and $7^{\circ} 33^{\prime}$ North and longitudes $4^{\circ} 30^{\prime}$ East and $4^{\circ} 35^{\prime}$ East. It is characterized by distinct dry and wet seasons with about 5 to 6 months of sufficient rainfall for plant growth (Ayoade, 2003; Sawa, \&Adebayo, 2011; Salami, \&Sangoyomi, 2013). IRDP was conceived in part as a means of extending practical knowledge acquired from the university research activities to neighbouring rural communities. However, despite the almost two-decade extension services to the areas, there have not been remarkable changes in the small-holder farmers patterns of life (Ladipo, \& Adesimi, 1977; Adeniyi, 1988), cultural practices (Salami, Kamara, \& Brixiova, 2013; Obayelu, 2012) and decision-making processes which centre on subsistence orientation(Nose, \& Yamauchi, 2012; Fan, Brzeska, Keyzer, \& Halsema, 2013) .

The choice of IRDP for this research was based on the ease of access to the villages, ready acceptability of researchers by the farm operators, the good representativeness of typical rural communities, ease of collecting accurate information on typical small-holder farming and more importantly, the study was at the request of the sponsoring agricultural extension and rural sociology department for performance evaluation.

\section{Methodology}

The data used were obtained from 200 farmers who co-operated fully out of the 225 samples randomly taken from the 2,265 small-holder food crop farmers participating in theorganized and sponsored farm groups of Isoya Rural Development Projects (IRDP) of ObafemiAwolowo University, Ile-Ife. Data Collection was done through farm survey using Questionnaire schedule administered in the 2009 and 2010 cropping seasons to revalidate the data with those obtained from similar surveys previously carried out between 1987 and 1999 in the study area (Adeniyi, 1988).

Budgetary analysis techniques were used to estimate the net farm income per farmer as currently observed. The conventional linear programming (LP) technique was applied to obtain the optimum combination of food crop enterprises, given the current level of resources. Optimum results were subjected to sensitivity analysis in order to determine the effects of alternative events on income.

In order to fit the observed results to a suitable linear programming framework, a representative farm was chosen to depict a typical average farm having the following characteristics:

(a) a land area of 2.37 hectares, equivalent to the average farm size per farmer (or 473.95 hectares for 200 sample farmers);

(b) an average amount of $\$ 950,000$ capital comprising about $\$ 500,000$ owned capital, $\$ 290,000$ loan from formal sources with 18 percent interest per annum and $\$ 160,000$ informal loan with an assumed annual interest rate of 5 percent, required for operating the specified farm size;

(c) an average monthly labour force of about 30 standard man days available per farming household out of which only 20 percent of the amount used was hired. Women and children contributed only 10 percent of the work output of adult males.

(d) a minimum quantity of each food crop required per farming household estimated on bulk weight consumed (Okuneye, 1985; Myers, \& Bobape, 2007).

Minimum quantity consumed is better estimated on bulk weight since the value attached to nutrient is of minimal importance in the selection of subsistence household diets (FAO, 2010; Kennedy, Razes, Ballard, \& Claude, 2010; WFP, 2009)

Most studies on minimum household requirements therefore found it convenient to use the bulk weight consumed in preference to nutrient quantity because while the former is positive and measures the actual intake per period of time, the latter is normative in nature (Smith, 1959; Stigler, 1945). In this analysis, the minimum household requirement was estimated on the basis of information collected from small-holder farmers on the quantity of each food crop produced and consumed directly by the farm family (Quackenbush, 1954).

\subsection{Some Socio-Economic Characteristics of Small-Holder Farmers}

Farm practice in IRDP areas, typical of the rainforest zones of South-western states of Nigeria is largely traditional. The major farming inputs are land, family labour, hoes and cutlasses. Labour is occasionally hired during the peak periods of production and harvesting. Output of food crops is chiefly intended to meet family needs. 
Most of the farmers are advanced in age, with mean and modal ages being 52 and 64 years respectively. About 67 percent of the sample are non-literates but with long years of farming experience ranging between 28 and 35 years. The available family labour is composed of 2 men, 2 women and 2 children (4.5 man equivalents) and an average of 5 hours daily farm work are recorded for an adult male as against the standard 7.5hours (Ariyaegbunam et al., 2010; Omotayo, 2010; Okoh, Rahman, \& Ibrahim, 2010; Okoye, Agbaeze, Asumugha, Aniedu, \& Mbanaso, 2009). The use of chemical is limited on the farm and only 47 percent use fertilizer, 12 percent use insecticides and 5 percent use herbicides.

The major crop recommended officially by the State ministries and Faculty of Agriculture extension programme is the cultivation of maize as a sole crop. However, the field study revealed that farmers planted maize both as sole and more often with root crops such as cassava, yam, cocoyam and plantain.

Bush fallowing was still being practiced by the farmers in spite of the age-long encouragement on adoption of fertilizer usage.

\subsection{The Model}

Two sets of objectives were assumed for farmers in respect of their production decisions, given their present level of resource inputs, prices and mode of production. The first objective was specified by imposing a constraint defining a minimum production level that satisfies the household consumption requirements. This is to reconcile the goals of profit maximization and subsistence in smallholder food crop farming. The second situation relaxed the imposition of this minimum household consumption requirement, and allowed farmers the freedom to produce with the sole objective of profit maximization. The optimum plans are thus discussed under these two sets of assumptions.

\section{Discussion of Results}

Table 1 compares the representative farm's budgeting plan for 2009/2010 with the basic optimum plans arrived at through the linear programming method.

With the twin assumption of profit maximization and the provision of the household minimum food requirements, the optimum farm size for the smallholder farmer is 1.415 hectares rather than 2.370 hectares being cultivated by the farmers. Income per hectare consistent with this optimum farm size is $\$ 318,180.52$, a 93.76 percent increase over $164,213.88$, the observed situation. Gross margin per hectare increased by 108.39 percent over the observed plan, from $\$ 177,648.60$ to $\$ 370,196.29$. However, this optimum farm size would require about 204.52 man days

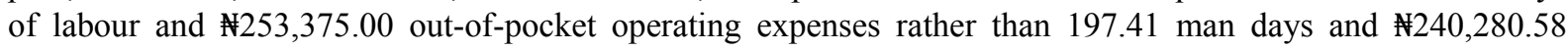
respectively in the observed plan.

In the observed plan, maize was the most preferred among sole crop enterprises and among crop mixtures, maize/cassava enterprise was most favoured. This situation is however not unexpected in view of the emphasis of extension advice on mass production of maize as a policy towards massive grain production in the government programme.

The optimum plan recommends the use of 0.588 hectare (or 41.6 percent) 0.343 hectare (or 24.2 percent) 0.222 hectare (or 15.7 percent) for the production of cassava/yam, maize/yam and maize/cocoyam respectively. Sole cropping of any of these crops is totally rejected in the optimum plan. Banana/Plantain sole crop only came into the programme because of the requirement to satisfy the minimum production constraint specification.

The optimum plan without minimum subsistence production restriction showed that maize/cassava/yam $(0.733$ hectare), cassava/yam ( 0.476 hectare) and maize/cocoyam ( 0.422 hectare) should be planted by the small holder farmer on 1.631 hectares rather than the 1.415 hectares of land utilized when the minimum production specification was imposed. This gives an improvement of only $1,108.87$ (or 0.35 percent) in net farm income per hectare above that with subsistence family food requirements included as constraints. Sole cropping of any crop was not profitable, even in this model also. However, the major difference between the two optimal plans with and without minimum household requirement constraints respectively is the entry of banana-plantain in the former but not in the latter.

In order to determine the better of the two optimal plans therefore, an allowance is made for a situation when the operator considers the purchase of minimum household requirements from the revenues realizable when profit maximization is the only objective of farmers. This exercise reduced the realizable net farm income to \#260,599.54, which is about 338.04 percent below the income earned with the current management practice. This therefore implies that the optimum plan with the dual restriction of profit maximization and minimum household requirements was economically more satisfactory and preferable. 
Table 1. Budgetary and optimum plans for the average representative farm

\begin{tabular}{|c|c|c|c|c|}
\hline \multirow{2}{*}{\multicolumn{2}{|c|}{ A.Crops (in hectares) }} & \multirow[b]{2}{*}{$\begin{array}{l}\text { Budgeting } \\
\text { (ObservedPlan) }\end{array}$} & \multicolumn{2}{|c|}{ Linear Programming (Optimum Plans) } \\
\hline & & & \multirow[t]{2}{*}{$\begin{array}{l}\text { Profit Maximization with } \\
\text { Minimum Subsistence Family } \\
\text { food Requirements (Basic) }\end{array}$} & $\begin{array}{l}\text { Profit maximization } \\
\text { Objective only }\end{array}$ \\
\hline \multicolumn{2}{|c|}{ Maize } & 0.798 & & \\
\hline \multicolumn{2}{|c|}{ Cassava } & 0.471 & & \\
\hline \multicolumn{2}{|c|}{ Yam } & 0.197 & & \\
\hline \multicolumn{2}{|c|}{ Cocoyam } & 0.108 & & \\
\hline \multicolumn{2}{|c|}{ Banana-Plantain } & 0.051 & 0.262 & \\
\hline \multicolumn{2}{|c|}{ Maize/Cassava } & 0.335 & & \\
\hline \multicolumn{2}{|c|}{ Maize/Yam } & 0.039 & & \\
\hline \multicolumn{2}{|c|}{ Maize/Cocoyam } & 0.033 & 0.222 & 0.422 \\
\hline \multicolumn{2}{|c|}{ Cassava/yam } & 0.047 & 0.588 & 0.476 \\
\hline \multicolumn{2}{|c|}{ Cassava/cocoyam } & 0.166 & & \\
\hline \multicolumn{2}{|c|}{ Yam/cocoyam } & 0.023 & & \\
\hline \multicolumn{2}{|c|}{ Maize/Cassava/Yam } & 0.064 & 0.343 & 0.733 \\
\hline \multicolumn{2}{|c|}{ Maize/Cassava/Cocoyam } & 0.037 & & \\
\hline \multicolumn{2}{|c|}{ Total (hectares) } & 2.37 & 1.415 & 1.631 \\
\hline \multicolumn{2}{|c|}{ Labour required (man days) } & 197.41 & 204.52 & 208.32 \\
\hline \multicolumn{2}{|c|}{ Operating expenses (\#) } & $240,280.58$ & $253,375.00$ & $263,902.44$ \\
\hline & Gross margin Farm $^{-1}(\mathbb{N})$ & $421,027.19$ & $523,827.75$ & $591,748.46$ \\
\hline & Gross margin ha ${ }^{-1}$ & $177,648.60$ & $370,196.29$ & $362,813.28$ \\
\hline & Gross margin man day ${ }^{-1}$ & 899.90 & $2,561.25$ & $2,827.00$ \\
\hline & $\begin{array}{l}\text { Gross margin man } \\
\text { hour }^{-1}\end{array}$ & 119.99 & 341.50 & 376.33 \\
\hline \multirow[t]{2}{*}{$\mathrm{C}$. } & Net Farm Income ( $\mathbb{*}$ ) & $389,186.89$ & $450,225.44$ & $517,143.86$ \\
\hline & Net Farm Income ha $^{-1}$. & $164,213.88$ & $318,180.52$ & $317,071.65$ \\
\hline \multicolumn{5}{|c|}{ D. Marginal productivity : } \\
\hline (i) & Land(Naira ha ${ }^{-1}$ ) & - & - & - \\
\hline & Owned capital (\#) & - & 1.12 & - \\
\hline & $\begin{array}{l}\text { Borrowed capital( } \mathbb{N}) \\
\text { (formal source) }\end{array}$ & - & 0.94 & - \\
\hline \multirow[t]{2}{*}{ (iv) } & $\begin{array}{l}\text { Borrowed capital( } \mathbb{N} \text { ) } \\
\text { (informal source) }\end{array}$ & - & 1.07 & - \\
\hline & Labour ( $\mathbb{N}^{\prime}$ manday $^{-1}$ ): & & & \\
\hline \multirow[t]{2}{*}{ (v) } & - March /April & - & 8.83 & - \\
\hline & -May/June & - & 16.92 & - \\
\hline
\end{tabular}

Source: Authors' computation from Field Survey, 2011.

\subsection{Alternative Strategy for Maize Production}

The linear programming solutions show that sole maize production is not as profitable as crop mixtures involving maize with cassava, cocoyam and with cassava/yam. However, one of the main policies of extension services in the IRDP scheme and of course in alignment with government policy is to encourage production of maize 
massively. To this end, an analysis of a possible strategy for achieving the twin goals of profit maximization and subsistence on smallholder farms such that the extension policy on maize production would not be thrown out completely is considered logical.

The LP model under "minimum subsistence family food requirements" shows that capital and/or labour for clearing and weeding are the main constraints to increased production. Most of the capital involved is on labourhiring hence both constraints identified can be eased by effective chemical weed control. This could greatly increase production and possibly change the farm plan.

Some parametric approaches were tried on the limiting constraints. In order to utilize the added resources fully, land was also parametricised. Table 2 summaries the programme that favoured sole maize production most.

Table 2. Alternative plan for maize production, profit maximization and minimum household requirements: linear programming results-value of programme: $\$ 702,717.95$

\begin{tabular}{|c|c|c|c|c|c|c|c|c|}
\hline \multicolumn{2}{|c|}{$\begin{array}{l}\text { Activities in } \\
\text { solution }\end{array}$} & \multicolumn{3}{|c|}{ Fully used Resources } & \multicolumn{2}{|c|}{$\begin{array}{l}\text { Cost of forcing in Real non-optimal } \\
\text { activities }\end{array}$} & \multicolumn{2}{|c|}{$\begin{array}{l}\text { Total production of } \\
\text { crops }\end{array}$} \\
\hline Activity & Amount & Resources & MVP & & Activity & MOC(\#) & Crop & $\begin{array}{l}\text { Quantity } \\
\text { (tonnes ) }\end{array}$ \\
\hline $\mathrm{Mz}$ & 3.48ha & $\begin{array}{l}\text { Cash } \\
\text { owned }\end{array}$ & 3.47 & & Css & 231,350 & $\mathrm{Mz}$ & 5.413 \\
\hline $\mathrm{Css} / \mathrm{Ym}$ & $0.25 \mathrm{ha}$ & Cash $\mathrm{B}_{1}$ & 3.29 & & $\mathrm{Ym}$ & 769,290 & Css & 1.835 \\
\hline $\mathrm{Mz} / \mathrm{Cc}$ & $0.22 \mathrm{ha}$ & Cash $\mathrm{B}_{2}$ & 3.42 & & $\mathrm{Cc}$ & 645,860 & Ym & 1.640 \\
\hline $\mathrm{Bn}-\mathrm{Pt}$ & $0.26 \mathrm{ha}$ & & & & $\mathrm{Mz} / \mathrm{Css}$ & 186,500 & $\mathrm{Cc}$ & 0.988 \\
\hline Cash $\mathrm{B}_{1}$ & $\mathrm{~N} 290,000$ & & & & $\mathrm{Mz} / \mathrm{Ym}$ & 667,240 & $\mathrm{Bn}-\mathrm{Pt}$ & 1.310 \\
\hline \multirow[t]{4}{*}{ Cash $\mathrm{B}_{2}$} & $\mathrm{~N} 160,000$ & & & & $\mathrm{Css} / \mathrm{Cc}$ & 303,700 & & \\
\hline & & & & & $\mathrm{Ym} / \mathrm{Cc}$ & 673,360 & & \\
\hline & & & & & $\mathrm{Mz} / \mathrm{Css} / \mathrm{Ym}$ & 41,700 & & \\
\hline & & & & & $\mathrm{Mz} / \mathrm{Css} / \mathrm{Cc}$ & 602,560 & & \\
\hline \multicolumn{4}{|c|}{ MVP means Marginal Value Product } & Iz & $=$ Maize & & & \\
\hline MOC & \multicolumn{3}{|c|}{ "Marginal Opportunity Cost } & Css & $=$ Cassava & & & \\
\hline $\mathrm{B} 1 ”$ & \multicolumn{3}{|c|}{ Borrowing from formal source } & $\mathrm{Ym}$ & $=$ Yam & & & \\
\hline B2” & \multicolumn{3}{|c|}{ Borrowing from informal source } & $\mathrm{Cc}$ & $=$ Cocoyam & & & \\
\hline $\mathrm{Ha}$ & \multicolumn{3}{|l|}{$=$ hectares } & $\mathrm{Bn}$ & $\mathrm{Pt}=$ Banana or & antain & & \\
\hline
\end{tabular}

Source: Authors' computation from Field Survey, 2011.

As shown in Table 2, a land size of 3.48 hectares ( 82.66 percent) of the optimal land allocation was cultivated to sole maize. Other crops that are in the optimum plans only came in to satisfy the minimum production specification in the original basic matrix. This result is sharp contrast to the previous optimum plan (Table 1) where none of the sole cropping enterprises was optimal.

With a gross margin of $\$ 702,717.95$, the latter model (Table 2) predicts an average increase of $178,890.20$ (34.15 percent) in farm gross margin above the preferred optimum plan with minimum production requirements. The optimum net farm income of $\$ 653,214.64$ realized in the model also represents an improvement of 45.09 percent above the preferred model (Table 1, column 3 ) that rejected the sole cropping alternative.

\subsection{Stability of the Plans}

The stability of the optimal plans presented in Tables 1 and 2 are investigated by varying the level of prices. Nuthall, (1973) observed that changes in an activity's optimal level can occur if changes in at least one of the following parameters occurred:

(i) Product price;

(ii) Variable input cost; 
(iii) Input - output coefficients;

(iv) Resource levels.

None the less, Okuneye, (1985) established that product price changes are the most important in causing changes in optimal solutions.

Apart from establishing the price levels at which initial optimal activities would cease to be optimal, the sensitivity analysis will indicate the levels at which those non-optimal activities could become profitable. The price of each of the non-optimal activities is increased by 10-50 percent above that of the basic plan and decreased by $5-10$ percent for those of the optimal activities. Table 3 presents the results obtained from these analyses with reference to Table1.

Table 3. Effect of percentage change in prices on optimal conditions for the plans

\begin{tabular}{lllllllll}
\hline Enterprise/Activity & \multicolumn{7}{l}{ Percentage Change in activity's basic gross margin (PositiveorNegative) } \\
\hline Abbreviations & $-10 \%$ & $-5 \%$ & Basic & $10 \%$ & $20 \%$ & $30 \%$ & $40 \%$ & $50 \%$ \\
$\mathrm{Mz}$ & 0 & 0 & 0 & 0 & 0 & 0 & 1 & 1 \\
$\mathrm{Css}$ & 0 & 0 & 0 & 0 & 0 & 0 & 0 & 0 \\
$\mathrm{Ym}$ & 0 & 0 & 0 & 0 & 0 & 0 & 0 & 0 \\
$\mathrm{Cc}$ & 0 & 0 & 0 & 0 & 0 & 0 & 0 & 0 \\
$\mathrm{Bn}-\mathrm{Pt}$ & 0 & 0 & $1 *$ & 0 & 0 & 0 & 1 & 1 \\
$\mathrm{Mz} / \mathrm{Css}$ & 0 & 0 & 0 & 0 & 1 & 1 & 1 & 1 \\
$\mathrm{Mz} / \mathrm{Ym}$ & 0 & 0 & 0 & 0 & 0 & 0 & 0 & 0 \\
$\mathrm{Mz} / \mathrm{Cc}$ & 0 & 1 & 1 & 1 & 1 & 1 & 1 & 1 \\
$\mathrm{Css} / \mathrm{Ym}$ & 0 & 0 & 1 & 1 & 1 & 1 & 1 & 1 \\
$\mathrm{Ym} / \mathrm{Cc}$ & 0 & 0 & 0 & 0 & 0 & 0 & 1 & 1 \\
$\mathrm{Mz} / \mathrm{Css} / \mathrm{Ym}$ & 0 & 1 & 1 & 1 & 1 & 1 & 1 & 1 \\
$\mathrm{Mz} / \mathrm{Css} / \mathrm{Cc}$ & 0 & 0 & 0 & 0 & 1 & 1 & 1 & 1 \\
\hline
\end{tabular}

*Optimal because of minimum production constraint specifications

1 means the activity becomes optimal

0 means the activity becomes non-optimal

Index

$\mathrm{Mz}=$ Maize

Css $=$ Cassava

$\mathrm{Ym}=\mathrm{Yam}$

$\mathrm{Cc}=$ Cocoyam

$\mathrm{Bn}=$ Banana

$\mathrm{Pt}=$ Plantain

Source: Authors' computation from Field Survey, 2011.

Among the sole crop enterprises, maize and plantain entered the basic programme only with a minimum of 40 percent increase in their gross margins. Plantain entered the programme earlier only to satisfy the minimum production constraint in the basic matrix. Only maize/yam enterprise among the crop mixtures failed to enter the programme even with 50 percent increase in the gross margin. However, with the exception of cases where satisfaction of minimum household requirements is the only objective of farmers, maize/cocoyam and maize/cassava/yam enterprises would cease to be in the plan with a decrease of more than 5 percent in their prices while cassava/yam enterprises could remain in the programme if prices were not lower than the current level. 
For the alternative plans (Table 2), changes in the activity's gross margins and the marginal value productivities (MVP) of resources restrictions were examined to determine, the extent to which these changes could be made to favour maize production preferred by extension departments.

The advised optimum plan for maize production alternative (Table 2) will hold at the current price levels only if:

(i) All the available arable land (5 hectares per farm family) is fully utilized;

(ii) Effective labour availability is increased by 50 percent above the current level.

Also, most of the needed out-of- pocket expenses should be borne by the farm family with little or no external borrowing. Thus, introduction of labour saving adaptive technologies could significantly help to solve the problem of farm expansion.

\section{Conclusion}

Mixed cropping is very common among the smallholder farmers studied. Any possible combination of 2-or-3-crop mixtures of maize, cassava, yam, cocoyam and banana or plantain is generally undertaken by the farmer. This, in part, is to guarantee subsistence family requirements and also provide a basis for enhanced farm income. But contrary to official policy on development strategy, none of the sole cropping enterprises was optimal for the smallholder farmer given the current level of technology, resource availability, prices and objectives of the farmer.

However, owing to the multifarious use of the maize crop in live-stock industry and in human consumption, the adoption of sole cropping of maize by the small-holder farmer may be desirable and could be achieved through the alternative optimum plan presented in Table 2. A suggested 40 percent increase in the price of maize would encourage farmers in re-allocating greater resources to maize production thus increasing the total maize output. Alternatively, size of food crop farms could be increased by at least 50 percent of the current level to favour sole maize production. This would however require appropriate supplementation with extra labour to work the additional hectarage.

In order to make sole cropping especially of maize feasible for small-holder farmers therefore, there is need for measures to improve their farm productivity. Thus, measures such as formation of cooperative farm groups (Bhuyan, 2007; Kurimoto, 2002; Hermida, 2008), giving of guaranteed price incentives to farmers (Edward, 2009; Yamouri, 2008), extension of insurance facilities to arable crops (Gaul, Morgan, \& Cohen, 2006; Devereux, 2001), making labour-assisting technologies available for farmers use at cheap costs and encouraging the use of improved technological package (Akinwumi, 1971; Norman, Beeden, Haye, \& Huizinga, 1976) could help remove farm drudgery and guarantee increased farm income. On the other hand, these measures could lead to subsequent reductions of resources for other crop enterprises, hence a drop in the production of the other crops. Consequently, prices of these other food crops will rise thus leading to further food price inflation. However, these associated problems could also be checked by adopting improved production practices and labour saving technologies (Adeniyi, 1988; CSNRD-2, 1967).

\section{References}

Adeniyi, O. R. (1988). Farm Management decisions of small-holder farmers in Isoya group of villages. Unpublished Ph. D. thesis, Department of Agricultural Economics, Obafemi Awolowo University, Ile-Ife.

Adeniyi, O. R. (2012). Socio-economic Analysis of Subsistence Farming Practices in South Western Nigeria.Sustainable Agricultural Research (SAR), 2(1), 104-111.

Adesimi, A. A. \& Ladipo, O. O. (1983).Linear optimizing model for food crop enterprise selection in Ife area of Oyo State. Ife Journal of Agriculture, 5 (1 and 2), 35-42.

Akinwumi, J. A. (1971). Costs and Returns in Commercial Maize Production in the Derived Savannah belt of Western State, Nigeria. Bulletin of Rural Economics and Sociology, 7(2), 179.

Ariyaegbunam, H. N., Okoye, B. C., Asumugha, G. N., Ogbonna, M. C., Madu, T. U., Nwakor, N., \& Ejechi, M. E. (2010). Labour Productivity among small holder cassava farmers in South East Agro-Ecological Zone, Nigeria. .African Journal of Agricultural Research, 5(21), 2882-2885.

Attah, A. W. (2012). Food Security in Nigeria.The Role of Peasant farmers in Nigeria. African Research Review, Ethiopia, 6(4), 173-190. http://dx.doi.org/10.4314/afrrev.v6i4.12

Ayoade, J. O. (2003). Climate change: A synopsis of its nature, causes, Effects and Management. Vantage Publishers Ltd. 98A Samonda, Oyo Road, Old Airport Area, Ibadan, Nigeria.

Bhuyan, S. (2007). The people factor in cooperatives, an analysis of members. Canadian Journal of Agricultural Economics, 55(3), 275-298. http://dx.doi.org/10.1111/j.1744-7976.2007.00092.x 
CSNRD-2, (1967). Comments of the relationship between Nutritional needs and development planning in Nigeria. Consortium for the Study of Nigerian Rural Development.

Devereux, S. (2001). Livelihood Insecurity and Social Protection: A Re-Emerging issue in Rural Development. Development Policy Review, 19(4), 507-519. http://dx.doi.org/10.1111/1467-7679.00148

Edward, C. (2009). Agricultural subsidies. Eight types of Farm subsidy. CATO institute-downsizing the Federal Government, Retrieved October 15, 2013, from www.downsizinggovernment.org/agriculture/subsidies.

Enriquez, L. J. (2000). The varying Impact of Structural Adjustment on Nicaragua's Small Farmers. European Review of Latin American and Caribbean Studies, 69, 47-68

Fan, S., Brzeska, J., Keyzer, M., \& Halsema, A. (2013). From subsistence to profit: Transforming Smallholder Farms. Food Policy Report; IFPRI, Washington, D.C.

FAO. (2010). Food and Agriculture Organizations of the United Nations, Rome, Italy. Reprint, 2013. Retrieved October 15, 2013, from www.fao.org/docrep/014/i198e/i1983e00

Gaul, G. M., Morgan, D., \& Cohen, S. (2006). Crop Insurers Piling up Record Profits. Washington Post, Oct. 16.

Giller, K. E., Witter, E., Corbeds, M., \& Tittonell, P. (2009). Conservation Agriculture and Smallholder farming in Africa: The heretics view. Field Crops Research, 114, 23-34. http://dx.doi.org/10.1016/j.fcr.2009.06.017

Hermida, J. (2008). Agricultural Cooperative in Asia. Retrieved October 15, 2013 from http://asiadhrra.org/wordpress/2008/01/11agric.coops-in-asia

Idachaba, F. (2004). Food Security in Nigeria: Challenges under democratic dispensation. Paper presented at ARMTI Lecture.

Kennedy, G., Razes, M., Ballard, T., \& Claude Dop, M. (2010). Measurement of Dietary Diversity for monitoring the impact of food based approaches. Part of published proceedings of the international symposium on food and Nutrition Security: Food-based approaches for improving diets and raising levels of nutrition 7-9 December, Rome, Italy.

Kurimoto, A. (2002). Evaluating Performance by Cooperative value and Efficiency. Nigerian Journal of Cooperative studies, 2(1), 39-54.

Ladipo, O. O., \& Adesimi, A. A. (1977). A System Analysis of decision-making under subsistence agriculture. ODU, University of Ife. Journal of African Studies, Ile -Ife, (16), 35-51.

Myers, R., \& Bobape, L. (2007). Analysis of household demand for food in South Africa: model selection, expenditure endogenity and influence of socio-demographic effects. Paper presented at the African Econometrics Society Annual Conference, Capetown.

Norman, D. W., Beeden, P., Haye, H. M., \& Huizinga, B. (1976). The feasibility of improved sole crop maize production technology for the small-scale farmer in the Northern Guinea Savannah Zone of Nigeria. Samaru Miscellaneous paper 59, Institute of Agricultural Research, Zaria.

Nose, M., \& Yamauchi, F. (2012). Long-Term Impacts of Global food crisis on Production Decisions: Evidence from Farm Investment in Indonesia. Policy Research Working 6065, World Bank. Washington D. C.

Nuthall, P. L. (1973). On the analysis of simplex linear programming solution tableaus with reference to net revenue stability limits. Journal of Agricultural Economics, 22, 49-60. http://dx.doi.org/10.1111/j.1477-9552.1971.tb01402.x

Obayelu, O. A. (2012). Saving behavior of Rural Households in Kwara State, Nigeria. African Journal of Basic and Applied Sciences, 4(4), 115-123

Okoh, S. O., Rahman, S. A., \& Ibrahim, H. I. (2010). Gender participation in commercial poultry production in Karu and Lafia Areas, Nasarawa State, Nigeria. Livestock Research for Rural Development, Vol. 22, Article No.160. Retrieved October 15, 2013 from http://www.lrrd.org//lrrd22/9/okoh22160.htm.

Okoye, B. C., Agbaeze, C. C., Asumugha, G. N., Aniedu, O. C., \& Mbanaso, E. N. A. (2009). Small is beautiful: Empirical evidence of an inverse relationship between farm size and production efficiency in smallholder cassava production in Ideato North L.G. A. of Imo state. National Root Crops Research Institute Publication. Umudike, Abia State.

Okuneye, P. A. (1985). Profit Optimization, improved farming methods and government objectives: A Nigerian $\begin{array}{llllll}\text { case study. Journal of Agricultural Economics, } & 36(1), & \text { 67-75. }\end{array}$ http://dx.doi.org/10.1111/j.1477-9552.1985.tb00157.x 
Olayide, S. O. (1976). Economic Survey of Nigeria, 1960-1975. Aromolaran Publishing Company Limited, Ibadan.

Oluwasola, O., Kasali, R., \& Amusan, C. A. (2012). Factors enhancing investment and farm capitalization in small holdings in Nigeria: Policy Implications for transforming the Agricultural Sector. International Journal of AgriScience, 2(3), 265-279.

Omotayo, A. M. (2010). The Nigerian Farmer and the Elusive Crown. 30 ${ }^{\text {th }}$ Inaugural Lecture, University of Agriculture, Abeokuta.

Oni, K. C. (2008). Transforming Agricultural Potentials to Wealth in Northern Nigeria. Invited Paper Presented at the Northern Nigeria Economic and Investment Summit (NEIS) Abuja, October 2008.

Quackenbush, G. G. (1954). Demand analysis from the Michigan State University Consumer Panel. Journal of Farm Economics, 415-427. http://dx.doi.org/10.2307/1233010

Salami, A., Kamara, A. B., \& Brixiova, Z. (2013). Smallholder Agriculture in East Africa: Trends, Constraints and Opportunities. Working Papers, series No. 105. African Development Bank. Tunis, Tunisia.

Salami, B. T., \& Sangoyomi, T. E. (2013). Soil Fertility Status of Cassava Fields in South Western Nigeria. American Journal of Experimental Agriculture, 3(1), 152-164.

Sawa, B. A., \& Adebayo, A. A. (2011). The Impact of Climate change on Precipitation, Effectiveness Indices in Northern Nigeria. Research Journal of Environmental and Earth Sciences, 3(5), 481-486.

Smith, V. E. (1959). Linear Programming Models for the determination of palatable human diets. Journal of Farm Economics, 272-283. http://dx.doi.org/10.2307/1235154

Stigler, G. J. (1945). The cost of Subsistence. Journal of Farm Economics, $303-314$. http://dx.doi.org/10.2307/1231810

World Food Programme (WFP). (2009). Comprehensive Food Security and Vulnerability Analysis Guidelines. United Nations World Food Programme, Rome, Italy.

Yamouri, N. (2008). Agriculture and Rural development in Mera /Middle East and North Africa. Retrieved 15th October, 2013, from http://go.worldbank.org/WMLZXRV380

Zhou, Y. (2013). Small holder Agriculture, sustain ability and the syngenta foundation for sustainable Agriculture. Retrieved October 16, 2013, from www.syngentafoundation.org/db/1/877

\section{Copyrights}

Copyright for this article is retained by the author(s), with first publication rights granted to the journal.

This is an open-access article distributed under the terms and conditions of the Creative Commons Attribution license (http://creativecommons.org/licenses/by/3.0/). 